\title{
Analysis of Urban Fabric: An Integrated Coastal Zone Management (ICZM) Approach for Sustainable Tourism Development in The Coastal Area of Bandar Lampung
}

\author{
Citra Persada $^{1, *}$, Yunita Kesuma ${ }^{1}$, Fadhilah Rusmiati ${ }^{1}$ \\ ${ }^{1}$ Departement of Architecture, Lampung University, Bandarlampung, Indonesia \\ *Corresponding author.Email: citra.persada@eng.unila.ac.id
}

\begin{abstract}
The coastal zone of Bandarlampung which grew as one of the economic development area in southern, is currently experiencing environmental degradation caused by trading activities, warehousing on a large scale. The natural resources in coastal area is holds high economic activity to create the tourism development based on local community in the future. The concept of Integrated Coastal Zone Management (ICZM) can ensure the sustainable use of natural resources, the environment and landscapes into account in harmony with economic, social and cultural development. This paper aims to identify the urban fabric as physical form of coastal land resources for the data based information, then provides the potential analysis for tourism development strategies with understanding to the built environment especially the urban fabric. A qualitative research method is used to observing the solid-void forms and linkage elements on the coastal area landscape. Based on this study, the character of solid-voids and linkage element is also influenced by the cultural, political, social and economic of the community. The characteristic of urban fabric can be the basic concept to develop the thematic tourism zones of the coastal area. There are three thematic tourism concept: Negeri Mina Teluk Betung Selatan Zone, Negeri Mina Kangkung Zone and Negeri Mina Kunyit Zone. The result of this study can be the reference for local goverment and stakeholders to increase community empowerment, environmental conservation and community resillience. Furthermore, the characteristic of urban fabric in the coastal area can be considered to create the sustainable tourism development planning based on ICZM concept.
\end{abstract}

\section{Keywords: Urban Fabric, Coastal Area, Sustainable, Tourism, Bandarlampung}

\section{INTRODUCTION}

The coastal areas are transitional areas between terrestrial and marine ecosystems which are affected by changes in land and sea. It have potential diversity of resources that holds high economic value and attraction to be created as tourism development. Bandar Lampung, which is the gateway of Sumatera, makes it a very strategic and potential area to be developed with natural resources, fisheries, ports, tourism and it can be provided as The National Strategic Area. As the capital of Lampung Province with the large of coastal area, Bandarlampung is located in Teluk Lampung and facing of Sunda Strait and Gunung Anak Karakatau. The coastal area in southern of Bandarlampung was grown as an embryo of the current urban development area. In the past, the old port activities including fishermen livelihood and fishery culture was the basic economic activities in coastal area of Bandarlampung. Then this area was extended to a large-scale trade, warehousing buildings, illegal buildings and substandard housing. Moreover, the coastal area of Bandarlampung has been overcrowded, limited of basic services, economic depression and considered to be slum area.

The coastal areas are faced with increasing pressures of urban development and have challenges with regard to their environmental protection [5] The sustainable tourism has the potential to become beneficial effects on the environmental protection, conservation and create high economic activities for community. It is a way to raise awareness of environmental protection and become a tool to increase the economic importance but does not destroy the natural resources on which the future of 
tourism will depend, notably the physical environment and the social structure of the host community. The sustainable tourism must become part of the natural, cultural and human environment, respecting the balance the characteristic of coastal areas [12] [8]. The Integrated Coastal Zone Management (ICZM) is a dynamic process of the sustainable management and the activities of coastal zones, taking into account at the same time the vulnerability of coastal ecosystems and landscapes, the diversity and interactions of activities, the maritime activities and identify their impact on both the marine and land parts. It is defined indicators of the development of economic activities to ensure sustainable use of coastal zones and reduce pressures that exceed their carrying capacity [10]. There are importing to analyzing the natural resources, built environment, socio-economic characteristics of the case study area.

This paper aims to identify the urban fabric as physical form of coastal resources for the data based information. Then provides the potential analysis for tourism development strategies with understandings to the built environment especially the urban fabric. It is focused on the coastal zone in several different administrative, there are Teluk Betung Selatan Subdistrict (Pesawahan) and Bumi Waras Sub-district (including Kangkung and Bumi Waras). The north is bordered by the Way Balau River and the east borders the Way Kunyit River. The case study is selected because there are included in the criteria of slum areas based on Bandarlampung Spatial Planning (RTRW) and The Decree of the Mayor of Bandar Lampung Number 406 / III.24 / HK / 2016 concerning the location of slum areas. In our approach we discuss the urban fabric and create spatial zoning concept for a sustainable tourism development of coastal area.

\section{LITERATURE REVIEW}

\subsection{Sustainable Tourism Development Concept}

Sustainable development can only work successfully when four elements there are economic, social, cultural and environmental elements have approximately equal importance and strength and interconnection without the domination of any part of these elements. Sustainable tourism concept mainly depends on the ability of the environment to ensure a stable and lasting basis for tourism development [1]. Sustainable tourism development is very important to manage of all resources in such a way that economic and social needs can be fulfilled while maintaining cultural integrity, essential ecological process, biological diversity and life support systems [15]. The planning process of sustainable tourism development steps in preparation, setting goals, examination of all elements, analysis and synthesis, formulation of plans and policies, formulation of recommendations and other implementation and monitoring application [4]. The three aspects of the tourism-environment relationship are (1) many features of the physical environment are consistently to be attractions for tourists, (2) tourism facilities and the infrastructure constitute the built environment, (3) tourism development and economic activities of an area generates an environmental impact [4]. Sustainability of the tourism industry is also reliant on local support, best obtained by encouraging local community to participate in all phases of tourist development [5].

\subsection{Urban Fabric: Solid-Void Forms and Linkage Elements}

The physical structure of the area will affect the image of an area and needed to be able to recognize and organize urban fabric elements into a coherent pattern [7]. The urban fabric consist of five elements: (1) paths: routes along which people move throughout the city; (2) edges: boundaries and breaks in continuity; (3) districts: areas characterized by special characteristics; (4) nodes: strategic focus points for orientation like squares and junctions; and (5) landmarks: external points of orientation, usually a easily identifyable physical object in the urban landscape. An environmental image has three components: identity (the recognition of urban entities), structure (the relation of urban elements to other objects), and meaning (its practical and emotional value of the area). With this concept, the urban inhabitants should be able to actively form their own livelihood stories and create new activities [7]. There are several the urban patterns that are texturally classified into three groups including: (1) the composition of homogeneous area with a structuring and textural pattern must be clear;

(2) The composition of heterogeneous area with two or more textural patterns; (3) The composition of the area is spread with chaotic tendencies [16].

The figure ground analysis explains the characteristics and deeper relationships related to the urban pattern between mass (solid) and space (void) [16]. The relationship of solid elements (building mass) and void (open space) that was called the configuration of urban pattern. It will be better achieved if the mass and space are connected and put together as a group interactions which producing several patterns and dimensions of urban units. The typology of relationship between urban solid and void of urban pattern that is texturally consist of six configuration patterns are grid, angular, curvalinier, radial concentric, axial and organic patterns [9].

Linkage element of urban pattern is derived from "lines" connecting one element to another. These lines are formed by streets, pedestrian ways, linear open spaces, or other linking elements that psychically connect the parts of a city. The linkage theory organizes a system of connections or a network, that establishes a structure for mass and open spaces. Linkage elements is a kind of 
urban adhesive interaction that forms and unites all the physical elements of an area. The urban linkage elements can be observed in different ways, including: visual linkage, structural linkage, and collective linkage [9]. Visual linkage can also connect two or more fragments of an area / city into one visual unit which defined lines, coridors, sides, axial and rhythm of solidvoid connections. The function of structural linkage in a city is as a stabilizer as well as a coordinator to make a unity of the solid-void connections. The collective linkage shows the overall related relationship of the characteristics and organization of the physical form [9].

\section{METHODS}

This paper used descriptive qualitative method which describes the spatial analysis of coastal area in Bandarlampung. The research based on applied research to identify and analyze the urban fabric form. According the research objectives, collecting data and information is provided by field obsevation of the existing coastal land condition to finding the texture, spatial pattern of the area (solid-void and linkage element). Then it is supported by in-depth interviews with community figures or actors related to develop the potential of socio-cultural, economic issues or problems and physical characteristics of the coastal area. Specifically, the research team will conduct observations and data collection in the coastal area of Teluk Lampung. Delineation of the observation area is identified in the southern part of the Laksamana Malahayati Road and Yos Sudarso Road considering in several different administrative, there are Teluk Betung Selatan Sub-district (including Pesawahan) and Bumi Waras Sub-district (Kangkung and Bumi Waras). The north is bordered by the Way Balau River and the east borders the Way Kunyit River.

\section{DISCUSSION}

\subsection{Sustainable Tourism Development Concept in Coastal Area}

The coastal zones well known with the vulnerability and the lack of disaster resilience. furthermore, the coastal area today is considered of slum area, poverty, lowest basic facilities and increasing of migration from inland areas. Not surprisingly, there is also a sharp conflict between the need for immediate consumption or use of coastal resources and the need to ensure the longterm supply of those resources is urgently needed to managed. Intregated Coastel Zone Management (ICZM) is a comprehensive approach known in the management of coastal areas which has been developed since a few decades ago. The objectives of ICZM concept are to solved the intersectoral problems in built environtment and natural resources in the coastal areas. The ICZM concept is created to begin the process of understanding the challenges facing the area and the environment challenges. The ICZM concept consist of several stage, there are establishment the goals and the engagement from stakeholder, analysis and futures the structure, setting the vision, designing the future strategies and realising the vision [11]. The coastal rural areas with the major activities in fishering and agricultural products for subsistence of the inhabitants and has been economic centers. it can be develop become recreation and tourism as major sources of domestic value and community empowerment $\mathrm{n}$ coastal areas [14]

The tourism development strategies have become an implement of city policy to ensure the urban renewal and refreshing urban image. It was aimed to increase the image branding and physical environment of the area by improving the environtment quality such as manage land use structures, reconstructing abandoned districts, renewing the old buildings and conservation of the heritage area [6]. Based on the relationship between sustainable tourism and tourism impacts in coastal cities have the possible negative and positive tourism impacts on the physical, economic and social structure of a city and the indicators of environmental sustainability, economic sustainability and social sustainability need to be determined in order to achieve sustainable tourism indicators [13]. Tourism can be an environmentally appropriate industry if managed correctly [5]. One of the tourism development concept was ecotourism which have the respect for nature, culture of the past and present, and the local people who have lived in a particular ecosystem for many years. Ecotourism can be effective in protecting both natural and human environments as well as sustainable development. The most important outcomes of ecotourism approach to local economic development is to create employment for local residents and earn revenue for them. in this way, the residents are encouraged to preserve the environment, customs and cultural traits that are attractive to tourists.

\subsection{Understanding Urban Fabric for Sustainable Tourism Development Concept}

The main stage to create sustainable tourism development based on the ICZM is formating an assemble of necessary information and data on the physical, economic, and social characteristics of the coastal zone [14]. The ability to determine the urban patterns can help deal with problems regarding accuracy and change in city design to determine basic guidelines for urban environmental design according based on the texture of the land. The function of structural patterns of a built environment is to create an understanding of how a city is formed and easily recognized [16]. The use of figure ground analysis is very appropriate in the discussion of urban patterns. The Urban patterns was textured with differences caused of the nuances of life and traditional architectural design and the livehood activities of local inhabitants. 


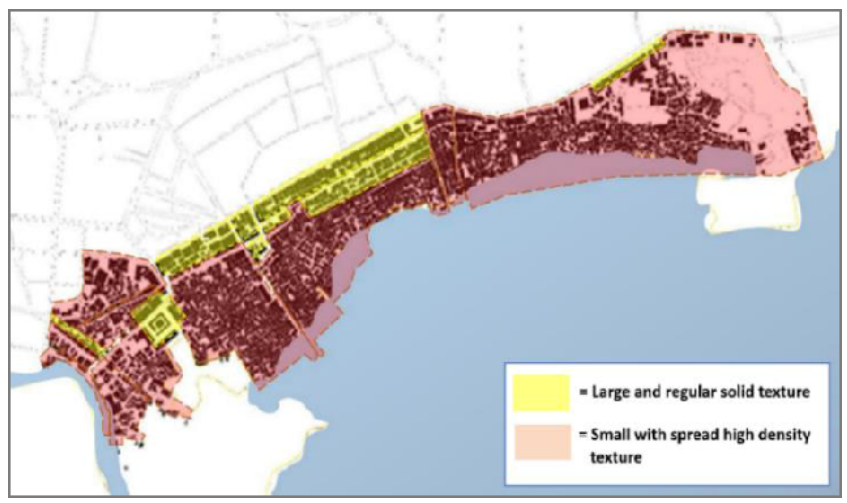

Figure 1 The Solid-Void Texture Element

The shape of the solid-void pattern in this cases study area consists of large building mass and the small building mass. the large building mass have regularly solid pattern which is dominated by comercial building such as trading, warehousing and services. it is established by following the main road direction (Laksamana Malahayati Street and Yos Sudarso Street) and come close to downtown. It is formed with a semiorganic grid pattern compatible with the pattern of urban village growth. Meanwhile, the smaller building mass have irregularly solid pattern but following the road position, shaped of human settlement which have high density and is located in the southern towards the sea direction. Generally, the coastal areas have a compact form, with various solid pattern, having high density with same direction (Figure 1).

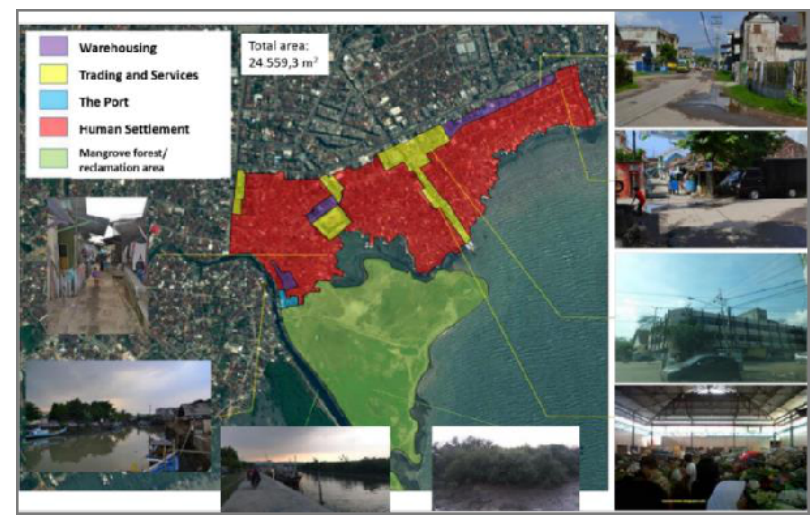

Figure 2 Land Use Classification of The Case Study

Land use involves the management and modification of built environment such as settlements, trading, infrastructure, facilities, open space, and the other activities that people in an urban area. Land use management practices have a major impact on natural resources including water, soil, nutrients, plants, and animals. Land use information can be used to develop solutions for natural resource management issues such as pollution, salinity, conservation, reconstruction and substandard environment quality. Land use classification is important as a standard for land use management. However, current land use classification in this case study area such as "residential use" and "commercial use" do not fully reveal how the land use is used in terms of function. generally in an urban area consist of mix use and land use changes over time. As a result, land use classification indicates biased segregation (Figure 2).

The land use classification in coastal area is dominated of human settlements and trading area. The human settlement characteristics in Kangkung are mostly of old residential with very high intensity, having floor average height of one floor. Meanwhile the largest of trading area consist of retail stores, grocery stores and house-shop located in Pesawahan and Kangkung, which have floor average height of two to three floors. The other is warehousing and educational facility such as Bumi Waras Primary School sre located in Bumi Waras. Based on the interviews with community leaders who live in Kangkung, several of human settlements where the people live in the coastal area is illegal. Since the 1990s the community began to make semi-permanent residence. Land title (ownership) become the main issues which is the important factor to manage the coastal area by the government. The residents who not having land ownership is taking rent from businessman or land owner. However, if the land is to be built by businessman or landowner, the residents must leave the land.

The landscape of urban open spaces can range from playground park, fields to relatively natural landscapes. Generally considered open to the public, urban open spaces are sometimes privately owned, such as residential neighborhood and institutional or corporate grounds. Open space provides recreational areas for residents and helps to enhance the beauty and environmental quality. but the open space in this area are felt to be very lacking. It is only available as smallsize park (Dipangga Park) around this area and traffic island appearing at Yos Sudarso Street. There are the large trees as a shade, but their presence is spread in several locations. Related to improving the quality of settlements and urban space, it is necessary to increase and fulfill the open space in this area.

\subsection{Analysis of Thematic Tourism Development Concept}

The texture of the area has implications for the character of urban area to be developed. The natural and environmental conditions, the character of solid-voids and linkage is also influenced by the cultural, political, social, and economic activities of the community. The texture of the area which mean the structure of land use and built environment was a part of spatial planning components. Spatial planning used by the government to improve economics, social and environments of communities. therefore, spatial planning is an important keys for promoting sustainable development and improving the quality of life. The objectives of the action strategies in spatial planning can be determined with development zone that was called zoning plan. Despite 
these objectives may be pre-determined by legislation, policy, or policies, in many cases where the objectives are not performed and create imageablity from the area. the zoning plan is developed for more easily understood by the community to manage their own activities. From identification and analysis of the textural characteristics of the coastal area, there is obtained three zones that have different characters. It can be used to strenghten and shaping image branding with the main concept of sustainable tourism development.

Determining tourism potential, it will be analyzed based on 3 A, namely attraction, accessibility amenities and ancilliary [3][2]. The river, mangrove forest is the natural attractions around the site that can be used as a tourist attraction. Besides fisherman way of life, the historical story of the coastal area can be the social attraction. The amenities including accommodation (lodging, travel and tour agent), culinary (restaurants, cafes, food stalls, snack shops) and supporting facilities (like hospital, mosque).The nearest hotels in Teluk Betung Selatan Subdistrict are Yunna Hotel and Sriwijaya Hotel among $2 \mathrm{~km}$ or 10 minutes from the case study area. The accesibilities is quite easy with about $6 \mathrm{~km}$ from the CBD of Bandar Lampung (Tanjung Karang), it can be reached via the main road (Laksamana Malahayati Street and Yos Sudarso Street). The external accessibilities can be reached through Raden Intan 2 Airport, Bakauheni Port and Tanjung Karang Station. The ancillary is relating to the availability of an organization or people who take care of these destinations. Fisherman and local entrepreneur can perform as community organization to managing the destination collaborated with local governments and other stakeholders. Based on the physical, social and economic analysis above, the case study area have the potential to be developed as a "Mina" tourist. The concept of "Mina" tourism is generating urban villages to develop social, economic and cultural life oriented to fisheries and marine life.

1. Zone A is located in Pesawahan (Teluk Betung Selatan Sub-district) with a high level of accessibility. The area have a heterogeneous solid texture which is dominated with the large (solid) mass that identify as culinary building. It is forming an angular solid-void linkage (triangle) configuration of several organic shapes following the curve-shaped linkage of Way Balau River. The issues from this area is solid waste pollution, and the low quality of the water and sedimentation. Based on land use analysis, this is provided with the mangrove forest as a buffer betwen land and sea from floodwaters, abration and storm surges from the sea. The estuary of Way Balau River where is the meets of salt water and fresh water that is called brackish water streams with having a free connection to the open sea. Beside keeping on biodiversity, it is become the nurseries of the oceans because it provide a safe area for fishing industries and tourist attractions. Based on the study, there are old warehousing and old port during Dutch colonization that have the potential to bring up the image of the area as a historic area. We proposed that Zone A can be developed for thematic tourism development Negeri Mina Teluk Betung Selatan Zone for seafoods and traditional culinary tourism with Way Balau river bank tour with fishing boat attractions. This concept is chosen to generate the image with exploring the past memories and giving a new tourist experiences of coastal area (Figure 3).

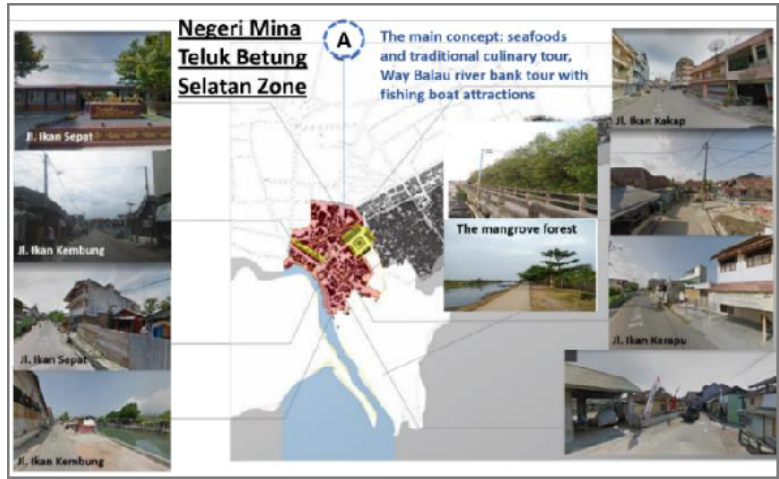

Figure 3 Negeri Mina Teluk Betung Selatan Zone Concept

2. Zone B is a part of Bumi Waras Subsistrict (Kangkung), tend to be homogeneous with regular pattern of the large scale of building mass (solid) on the edge (Laksamana Malahayati Street). This area is dominated of commercial function such as trading, services and werehousing. The small-sized building mass which is human settlement areas is spread and more organized than zone $\mathrm{A}$ and $\mathrm{C}$, and move away from a large building mass towards the sea in the southern. The issues from this area was high density building mass, substandard of human settlement, poverty, land ownership, lack of basic infrastructure and tend to become slum area. The community's livelihoods in the lowest part of zone B are fishermen and laborers. Even though the area have some of physical issues, the fisherman community and cultural fisheries life is very impresive and quite good. This area have lagoon area that potentially to be developed as tourism attraction. We encourage this area can be created with the thematic tourism development as Negeri Mina Kangkung Zone. It can be developed as coastal livehood and cultural tourism which called as fisherman village tourism. This concept is developed to improving the quality of the environment, directing the community to maintain environmental sustainability. It can be the reference for government to create local building code, architectural and environmental design, zoning regulation, social planning even urban spatial plan. Furthermore, the concept is needed for community resilience from natural disasters, social problems and economic changes (Figure 4). 


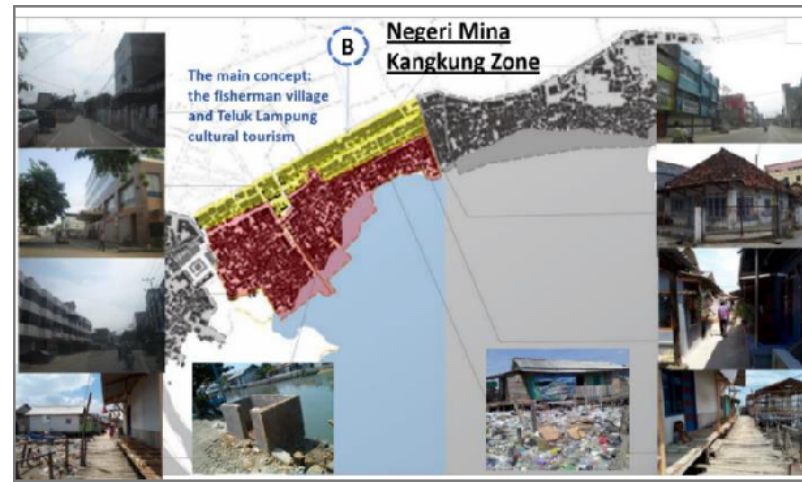

Figure 4 Negeri Mina Kangkung Zone Concept

3. Zone $\mathrm{C}$ is located in Bumi Waras (Bumi Waras Subdistrict) with textures that tend to be sporadically spread with the building mass is located at Yos Sudarso Street mass. its dominated by commercial area with the quantity are less than zone A and B. The smaller scale building mass which is the human settlement, tend to be chaotically spread and have high density towards the sea compared to zone A and $\mathrm{B}$. The livelihoods of the people in the lowest part of zone $\mathrm{C}$ are fishermen and laborers. Zone $\mathrm{C}$ have potential for the local economic activities with special handicraft such as kemplang crackers production, salted fish and the other fisheries production. Based on land use analysis, the existant of Bukit Kunyit is potentially developed for recreation and theme park. Currently, Bukit Kunyit is faces environmental degradation, therefore needs protection and conservation. The concept of sustainable tourism development can be choosen as a solution to raise awareness of environmental protection and become a tool to increase the economic importance but does not destroy the natural resources and the social structure of the host community [13] [9]. Considering the local community empowerment and conservation of Bukit Kunyit can become the basic theme to develop and manage Negeri Mina Kunyit Zone with Teluk Lampung leisure park and local handicraft shopping center. This concept aims to provide additional public open space for residents and the community. It creates new spaces for increasing social interaction and managing local economic production (Figure 5).

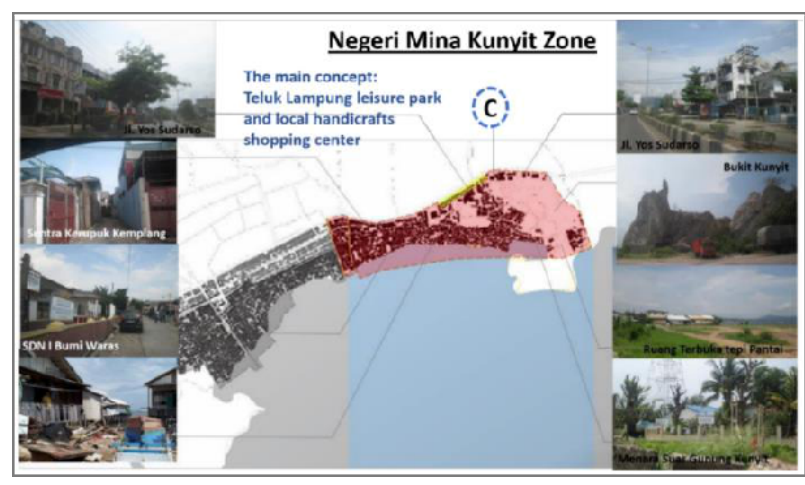

Figure 5 Negeri Mina Kunyit Zone Concept

\section{CONCLUSION}

Based on the results of the discussion, it can be concluded that the texture of the area (urban fabric) has implications for the character of urban tourism development concept. The character of solid-voids and linkage element is also influenced by the cultural, social and economic of the community. For createed the thematic tourism development concept based on Integrated Coastal Zone Management (ICZM) to provide the comprehensive strategic plan for tourism development involving carrying capacity, environtmental condition and natural resources in coastal area. The ICZM strategies can be supported by strenghten the tourism affairs including facilities, infrastructure, services, image branding, potential culture, human resources, comprehensive stakeholder concerned and financial. It can be obtained three zones of the coastal area that have different characters, which can be used as a strenghten concept to provide urban tourism development in the Bandarlampung coastal zone. There are 1] Negeri Mina Teluk Betung Selatan Zone has the potential to be developed as a culinary tourism and Way Balau river bank tour, 2] Negeri Mina Kangkung Zone can be developed as fisheries cultural tourism, and 3] Negeri Mina Kunyit Zone can be created as leisure park and local handicraft shopping center. In addition, the result of this research can be the reference to increase community empowering and resilience in economics, social and environment aspect. It can help the stakeholders to concern the characteristic of urban fabric and resources of coastal area to create the sustainable tourism development planning.

\section{ACKNOWLEDGMENTS}

The authors gratefully acknowledge the generosity of the research participants in sharing their time, experiences and the support from community organisations, academicians and local governments. This study was funded by The Research Grant Programme from University of Lampung in 2018. This programme provides financially supports for academicians and scientific research to enhance their skills, knowledge, and experience through their own research work. Applications for The Research Grant Programme are reviewed by panels of academicians and scientific research experts in engeneering and environmental science fields of study.

\section{REFERENCES}

[1] K. Angelevska-Najdeska, G. Rakicevik, Planning of Sustainable Tourism Development, Procedia Social and Behavioral Sciences 44 ( 2012 ) 210 220 (Amsterdam: Elsevier Ltd), 2012, doi: 10.1016/j.sbspro.2012.05.022 
[2] K.T.P. Arcana, K. Wiweka, A Study Of Indigenous Tourism Product Development Case Study: The Baduy, South Banten, West Java, Jurnal Ilmiah Hospitality Management, 2016, pp 65-74. Vol. 7 No. 1, Desember 2016 ISSN 2087 - 5576

[3] C. Cooper, et. al., Tourism Principles \& Practice, England : Longman Group Limited, 1993.

[4] D. S. Jurdana, Z. Sušilović, Planning City Tourism Development: Principles And Issues Tourism and Hospitality Management, 2006, pp. 135-144, Vol. 12, No. 2 (Croatia: Faculty of Tourism and Hospitality Management, University of Rijeka)

[5] R. Kay, J. Alder, Coastal Planning and Management, 2005, New York :Taylor \& Francis ISBN 0-203-49936-0 Master e-book ISBN, ISBN 0-203-34122-8, pp 54-69.

[6] C.M. Law, Urban Tourism And Its Contribution To Economic Regeneration, 1992, Urban Studies Vol $29(3,4)$, str. 599-618.

[7] K. Lynch, Good City Form, Cambridge: The MIT Press, 1984, pp 38-60.

[8] J. Swarbrooke, Sustainable Tourism Management, New York: CABI Publishing, 2000, pp13-41, pp 47-69

[9] R. Trancik, Finding Lost Space : Theories of Urban Design, New York:Van Nostrand Reinhold, 1986, Chapter 4: The Theories of Urban Spatial Design pp.97 - 124.

[10] United Nations Environment Programme (UNEP), ICZM in the Mediterranean (Split, Croatia : Mediterranean Action Plan on Priority Actions Programme Regional Activity Centre (PAP/RAC)) 2012, Available in http://www. papthecoastcentre.org.

[11] United Nations Environment Programme (UNEP), The ICZM Process:A Roadmap towards Coastal Sustainability, 2012. Link for download: http://www.pap-thecoastcentre.org/pdfs/ Protocol_publikacija_May09.pdf

[12] UNEP \& WTO, Guide for Local Authorities on Developing Sustainable Tourism. (Madrid : UNWTO), 1998, pp 194.

[13] B.O. Vehbi, A Model for Assessing the Level of Tourism Impacts and Sustainability of Coastal Cities in Strategies for Tourism Industry - Micro and Macro Perspectives, Dr. Murat Kasimoglu (Ed.) (Croatia : InTech Europe), 2012, ISBN: 978953-51-

0566-4 Available from:

http://www.intechopen.com/books/strategies-fortourism-industrymicro-and-macro-perspectives/a- model-for-assessing-the-level-of-tourismimpacts-and-sustainability-ofcoastal-cities

[14] World Bank, Guidelines for Integrated Coastal Zone Management in Jan C. Post and Carl G. Lundin (editors)( Washington, D.C.,USA : Environmentally Sustainable Development (ESD) Studies) Monographs Series No. 9, 1996.

[15] WTO, Indicators of Sustainable Development for Tourism Destinations (Madrid: WTO), 2004.

[16] M. Zahnd, Perancangan Kota Secara Terpadu, Yogyakarta: Kanisius, 2006, pp 79-130. 